\title{
Ethnobotany of suweg, Amorphophallus paeoniifolius: Utilization and cultivation in West Java, Indonesia
}

\author{
ASEP ZAINAL MUTAQIN ${ }^{1,2}$, DENNY KURNIADIE ${ }^{2}$, JOHAN ISKANDAR ${ }^{1}$, MOHAMAD NURZAMAN ${ }^{1}$, \\ RUHYAT PARTASASMITA ${ }^{1, \varphi}$ \\ ${ }^{1}$ Department of Biology, Faculty of Mathematics and Natural Sciences, Universitas Padjadjaran. Jl. Raya Bandung-Sumedang Km. 21, Jatinangor, \\ Sumedang 45363, West Java, Indonesia. Tel./fax.: +62-284-288828. "email: ruhyat.partasasmita@ unpad.ac.id; rp2010rikkyo@gmail.com \\ ${ }^{2}$ Program of Environmental Science, Postgraduate School, Universitas Padjadjaran. J1. Dipati Ukur 35, Bandung 40132, West Java, Indonesia
}

Manuscript received: 11 February 2020. Revision accepted: 25 March 2020.

\begin{abstract}
Mutaqin AZ, Kurniadie D, Iskandar J, Nurzaman M, Partasasmita R. 2020. Ethnobotany of suweg, Amorphophallus paeoniifolius: Utilization and cultivation in West Java, Indonesia. Biodiversitas 21: 1635-1644. Amorphophallus paeoniifolius (Dennst.) Nicolson, locally known as suweg, is a bulbous plant that has many benefits, but has not been cultivated as intensively as other species from the Araceae family. Suweg grows scattered in various rural areas in Indonesia, including West Java. Some suweg plants are cultivated by villagers, while the others grow wildly in forested areas. Suweg is commonly cultivated in several types of agroecosystems, such as home gardens (pekarangan) and gardens (kebun), using traditional ecological knowledge inherited from generation to generation. This study aims to investigate the utilization and cultivation of suweg by a community in Cisoka Village, Cikijing Sub-district, Majalengka District, West Java. This study used a qualitative method using ethnobotany approach, i.e. an emic analysis of the perception and local knowledge of community on suweg, and then validated using scientific or ethical knowledge. Field data collection was done by observation and semi-structured interviews with key informants chosen purposively considered having expertise and knowledge about suweg. The results showed that suweg has long been cultivated or growing naturally in Cisoka Village. The species has been culturally utilized by the rural community as additional food sources of carbohydrates, fish feed, and traditional ceremonies. However, the use of traditional ceremonies has been lost its importance. Suweg is generally used by the elderly, with certain groups, such as rural fish farmers and some younger age groups or children who like suweg. The rural people of Cisoka Village also mentioned that suweg was not cultivated as intensively as other. This is partly because it is considered not to have a high economic value as other agricultural commodities.
\end{abstract}

Keywords: Amorphophallus paeoniifolius, cultivation, ethnobotany, Sundanese people of West Java, utilization

\section{INTRODUCTION}

Indonesia is a country that has a very high diversity of plants. The diversity of plants in Indonesia is part of the Malesiana flora which is estimated to have around $25 \%$ of flowering plant species in the world with the number of species reaching 20,000 and of which $40 \%$ are endemic (Kusmana and Hikmat 2015). In rural areas, a variety of plants are considered useful, both growing wild in forest or cultivated by residents in various types of agroecosystems, such as home garden (pekarangan) and garden (kebun). In the home garden and garden systems, annual food crops are usually mixed with various perennial plants, as such the vegetation structure is very complex, resembling that of forest (Iskandar and Iskandar 2011, 2016; Njurumana 2016; Prihatini et al. 2018; Iskandar et al. 2017). Therefore, these systems play important role in delivering ecological services, including plant biodiversity conservation, maintaining soil fertility, soil erosion protection, and maintaining hydrological system of watershed (Iskandar 2017).

Rural ecosystems in Indonesia are usually composed of residential areas inhabited by villagers and agricultural lands. These ecosystems are influenced by various environmental factors (e.g. soil, climate, and water) which can affect their livelihood patterns as agrarian communities in such place (Development Team of Ministry of Education National 2011). In other words, villagers in their daily lives always have a very close reciprocal relationship with the environment or its ecosystem (Iskandar and Iskandar 2011; Iskandar 2017). The long experience of villagers interacting with their environment produces imagination and stories about their environment, including the species of plants, which form a very typical local knowledge system so-called Traditional Ecological Knowledge (TEK) (Cotton 1996; Iskandar 2018; Iskandar et al. 2019; Partasasmita et al. 2019). TEK has various peculiarities, such as being holistic, subjective and experiential; inherited by ancestors from generation to generation using mother tongue; learned by trial and error in interacting with environment, very deep but local, and vulnerable to extinction because it is not written (Ellen and Harris 2000; Sillitoe 2002; Berkes 2008; Iskandar 2018).

Specifically, TEK knowledge of rural communities in several regions of the world is cross-culturally related to names, folk classification, utilization, and traditional conservation of plant species. Zambrana et al. (2014) stated that the diversity of local names or TEK about plant species among them is influenced by several factors such as ethnicity, gender, and age. For example, Bari ethnic men in Venezuela have TEK about forest species rather than 
women. The reason is, Bari men have more experience dealing with plant species in the forest than the women (Zambrana et al. 2014). In contrast, the women of Matsigenka, Peru, have more in-depth TEK about species of medicinal plants than the men (Lizarralde 2004). The reason is, these women are usually more concerned with children and the health of women compared to men.

Related to TEK, the use of plant species by each ethnic is unique, meaning that it has its own principles and methods. Maroyi and Cheikhyoussef (2015) state that there are some similarities and differences in the use of plants in different countries in the context of the species of plants, organs used, how to prepare and the purpose of their use. Likewise, Mustafa et al. (2015) reveal that there are some differences in the use of plants by several ethnic groups related to the type of utilization and traditional knowledge in regard to the ecology of plants. Mardiyaningsih et al. (2010) inform that there are differences in agricultural systems in different places, mainly related to agrarian social structures such as land tenure patterns, work organization, production transactions, allocation of human resources, and planting culture rituals.

Amorphophallus paeoniifolius (Dennst.) Nicolson or suweg is widely spread and used in Indonesia (Yuzammi et al. 2017). Santosa et al. (2017) inform that suweg grows on several islands in Indonesia, such as Sumatra, Java, Bali and Lombok. Suweg has economic value for rural population as an additional staple food for carbohydrate sources, vegetables, and drugs such as anemia (Singh et al. 2010). Suweg can also be used for traditional medicinal including to treat bronchitis, asthma and dysentery, and ailment for poisonous snake bite (Ramanathan et al. 2014; Girardi et al. 2015; Dharmadasa et al. 2016). There are various methods of management system for suweg, but in general, it can be divided into two systems: grow naturally and being cultivated (Anil et al. 2011; Suja et al. 2012). For example, Mutaqin et al. (2020) mentions that suweg plants grow in West Java are found in several types of agroecosystems, such as home garden, garden, rice field, and pond edge, and grows wild in forest ecosystems.

Although suweg has many benefits, this plant has not been intensively cultivated by villagers. Therefore, studies on ethnoecology about suweg are very important. This study aims to investigate the utilization and cultivation of suweg (Amorphophallus paeoniifolius (Dennst.) Nicolson) by the community in Cisoka Village, Cikijing Sub-district, Majalengka District, West Java. This research is a followup study of folk classification, habitat, and traditional conservation of suweg plants in Cisoka Village.

\section{MATERIALS AND METHODS}

\section{Study area and period}

This research was conducted in Cisoka Village, Cikijing Sub-district, Majalengka District, West Java Province, Indonesia (Figure 1) in June-October 2019. It is at an altitude of 611 meters above sea level and located about $40 \mathrm{~km}$ from the district center, and $3 \mathrm{~km}$ from the sub-district center (Central Statistics of Majalengka District 2019). Administratively, Cisoka village has an area of 4.11 $\mathrm{km}^{2}$ and consists of 3 hamlets, 10 neighborhood residents (RW), and 21 neighborhood units (RT). The land use of Cisoka village consists of $14.76 \mathrm{Ha}$ of residential area, 194.19 Ha of paddy fields, $183.23 \mathrm{Ha}$ of plantations, 3.65 Ha of yards, $0.45 \mathrm{Ha}$ of offices, $1.9 \mathrm{Ha}$ of cemeteries, and 28.71 Ha of paddy fields (Cisoka Village Government 2016).
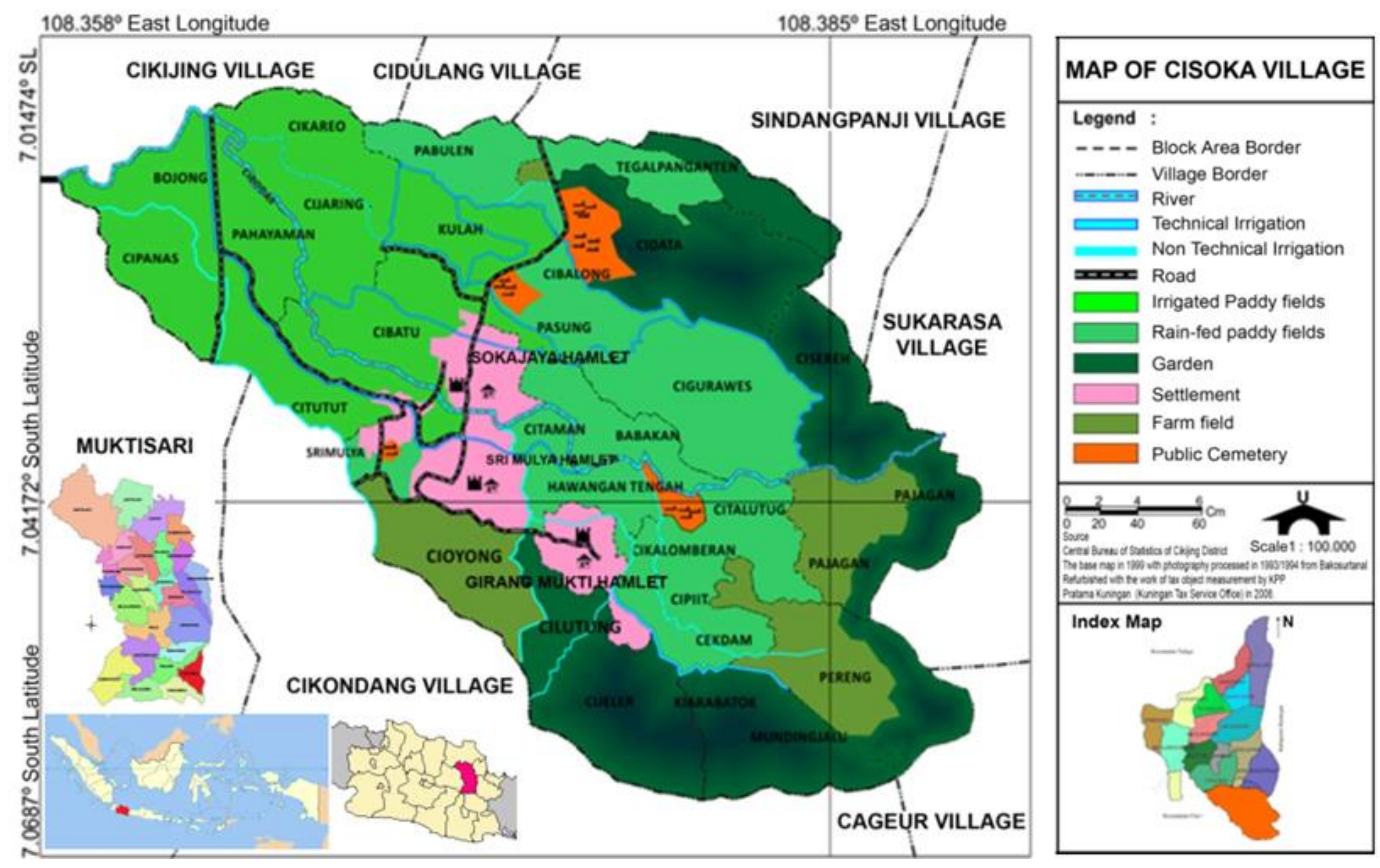

Figure 1. Location of research in Cisoka Village, Cikijing Sub-District, Majalengka District, West Java, Indonesia (Mutaqin et al. (2018) 
Based on population data in 2018, Cisoka Village has a population of 1,982 people, consisting of 981 men and 1,001 women, and a population density of $478 / \mathrm{km}^{2}$ (Central Statistics Agency of Majalengka District, 2019). The livelihoods of the population in Cisoka consist of 1078 farmers, 65 farm workers, 18 private workers/employees, 43 civil servants, 35 handicraft industries, 77 traders, 10 village officials, 11 animal breeder, 9 fish farmers, and 24 other livelihoods (Cikijing Sub-district Agricultural Counseling Center 2019).

The agricultural commodities in Cisoka Village are mainly rice (Oryza sativa L), shallots (Allium cepa $\mathrm{L}$ ), guava (Psidium guajava L), hot pepper (Capsicum frutescens L), water spinach (Ipomoea aquatica Forsk), cucumber (Cucumis sativus L), cayenne pepper (Capsicum annum L), and tomatoes (Solanum lycopersicum L) (Central Statistics Agency of Majalengka District 2019). In addition, several potential agricultural commodities are ginger (Zingiber officinale Roscoe), clove (Syzygium aromaticum (L) Merr and Perr), nutmeg (Myristica fragrans Houtt.), and coffee (Coffea arabica L.).

\section{Procedures}

This research is qualitative research with ethnobotany approach (Martin 1995; Cotton 1996; Cunningham 2001; Iskandar 2018). Field data collection was done using the methods of observation and semi-structured interviews. Observations were made through researchers observing the existence of the suweg in several types of agroecosystems, such as home gardens, gardens, and forest ecosystems. Meanwhile, the semi-structured interview was intended to gather information from the community about the use of suweg. Semi-structured interviews were conducted using snowball sampling technique by selecting informants who were considered competent. To explore local experts in Cisoka village, one could choose to work only with local experts representing a group of individuals who are socially legitimated as holders of a particular knowledge on suweg (cf. Albuquerque et al. 2014). The first informants interviewed were key/pivotal informants (informan pangkal), such as local government and community leaders. Subsequent interviews were conducted with other informants who were deemed to have knowledge about suweg with various backgrounds, who were recommended by the pivotal informants or previous informants. Some informants in this study were the village head, village staff, hamlet heads, olders and women farmers, ponds owners, and livestock owners. In semi-structured interviews, informants gave extensive responses to a series of general questions in relation with present of the suweg in several types of agroecosystem, including home garden and garden/mixed garden system; and various utilization of suweg, some of which had been prepared in advance and some of which were naturally given during the course of the conversation.

\section{Data analysis}

Data analysis was performed using an emic and ethical approach that was narrated descriptively through crosschecking, summarizing, and synthesizing (Newing et al.
2011; Iskandar 2018). Cross-checking is the stage to validate or correct the data obtained from various informants and the results of field observations. Summarizing is a stage to summarize data from informants or informants who have been validated. Synthesizing is done to make conclusions from data from informants or informants who have been validated and summarized. Next, a descriptive narrative analysis was made in sequence.

\section{RESULTS AND DISCUSSION}

\section{History of suweg in Cisoka Village}

In general, informants from Cisoka informed that Amorphophallus paeoniifolius (Dennst.) Nicolson, also known as local name is suweg, had been popular or had grown in the area where they lived since at least the 1950s, but it was not known exactly where it came from and since when it had been grown in the village. Various informants stated that the species that grew in several types of agroecosystems, such as their home gardens and/ or gardens, were unknown as to when they existed or were grown. The informants also informed that the presence or growth of suweg on their lands might at some time have a family member ever planted or removed the remaining skin or shoots of the suweg tubers in these types of agroecosystems. There were also several informants who inform that maybe someone else who dumped the remaining skin or tubers of suweg on their lands. In addition, various informants informed that existing suweg plants in their lands are allowed to grow to be used at a later time or harvest season when needed by their owners.

Related to the history of utilization, informants said that suweg had been used from generation to generation from its ancestors, although it was not known in a timely manner when it was used. Various informants also mentioned that suweg had been a staple food, besides rice, until around the 1970 s, especially during the dry season or when the rice not yet harvested. They also stated that suweg is still used until nowadays, although in general the use is limited to certain community groups, namely most older people, pond owners, and young people or children who like suweg. For young people or children who use suweg, their consumption is because of the many and various alternatives of food.

Regarding the unknown origin of suweg on community land and when it began to grow is in line with what was informed by Santosa et al. (2017) that this plant grows semi-wild. Plants that are wild or semi-wild, are different from plants that are cultivated by people who are generally of the origin of the seeds and the time of growth is known or cared for. For example, Makruf and Iswadi (2015) inform that the cultivation stages of taro, a plant biosistematically related to suweg, include the preparation of seeds, land preparation, planting, fertilizing, maintenance, control of plant pests, and harvesting. This is also in line with ethnobotany researchers that residents have local knowledge about the names of plants and uses, mainly because they get this knowledge inherited from 
their ancestors or based on personal experience during their lives in intensively interacting with these plants (Cotton 1996; Balick and Cox 1997). In other words, given the absence or scarcity of the story of the suweg plants from their ancestors and the plants had not been intensively cultivated by villagers, information about ecological history of suweg, such as when and how it was introduced, is less known.

The rationale for the use of suweg by the community until now is due to the benefits provided by the tuber. Various tubers of plants, including suweg tubers, have long been used by rural communities in West Java for various purposes. For example, Wigna and Khomsan (2011) mentioned that based on ecological history, in the past cassava tubers had been used by the people of Cireundeu Hamlet -Cimahi, West Java as staple food as a substitute for rice. Until now, the habit of consuming cassava as a substitute for rice still exists in the community of Cireundeu Hamlet-Cimahi, especially by the older generation. Similar to cassava, suweg in the past in the lean season was once used as a source of food for increasing food staple rice. But unlike the case of cassava food in Cireundeu, nowadays suweg is not consumed intensively by residents of Cisoka Village. Darpan et al. (2013) suggested that additional food sources of other carbohydrates, such as cassava or suweg, are important during famine season (i.e. season where staple food, e.g. rice, is in shortages) in rural populations. For example, Lukitaningsih et al. (2012) concluded that suweg (Amorphophallus paeoniifolius (Dennst.) Nicolson), walur (Amorphophallus variabilis), and porang (Amorphophallus oncophyllus Prain) tubers are alternative carbohydrate sources to substitute rice.

The results of the study showed that younger people did not use suweg more than the old age group. This is likely due to the erosion of TEK on suweg by the younger generation, or because of changes in their views on environment, including suweg plant species, and changes in the population of village subsistence livelihood. Several factors can cause the loss of traditional knowledge including formal education, bilingual, and subsistence modes (Lizzaralde 2004; Iskandar 2018). Meanwhile, Iskandar and Iskandar (2011) states that changes in the view of a community on its environment are due to several factors including formal education, religious education, and market economic factors.

\section{Utilization of suweg in Cisoka Village}

The community in Cisoka Village mentioned that suweg are often used for various purposes, namely food additives, fish feed, and traditional ceremonies (Table 1).
The existence of the use of suweg is proof that there is a community relationship with the surrounding environment. For example, Handavu et al. (2019) conclude that there is a strong dependency between local communities on the resources in their environment.

In general, suweg tubers that are used by people in Cisoka Village for supplementary food/ snack are generally consumed (jajabur in local language) for themselves and their families (subsistence) or shared with others in need such as neighbors. Suweg used as supplementary food is generally served or consumed together such as when mutual works, guest visits, or certain rituals in carrying out religious orders.

The informants in Cisoka Village also specifically informed the suweg tubers processed by steaming or in local terms called diseupan. The steaming is through several stages as follows: the tubers are peeled outside, then the tuber flesh is sliced/cut into thin pieces for 2 fingers or a portion of citrus fruit (about $3 \mathrm{~cm}$ ), not thick so that it does not itch. Then, the tubers are washed with water (preferably with running water to get rid of itching) and the tuber steamed (about 30 or 60 minutes). Lastly, the steamed tubers are given grated coconut and salt to be served/eaten. Steamed tubers served with grated coconut and salt in local terms are called urab. The steamed/ cooked tuber is a fresh tuber or the period is not long after it is harvested, so that it tastes good because if it is not cooked it is immediately unpleasant or teu puleun (in the local language). Processing tubers for food is rarely boiled or dikulub (in the local language) because it can cause the destruction of the tubers. A more detailed description of suweg's tuber processing for supplementary food can be seen in Figure 2.

People also used suweg to feed fish, especially gurame (Osphronemus goramy), mujaer (Oreochromis niloticus), nilem (Osteochilus vittatus), and mas (Cyprinus carpio). Utilization for fish feed is done if the leaf strands have started to appear (about 1 month after the emergence of shoots) and if the tubers will not be used in the season. This is because the strands/ leaf stems of suweg are still in the process of growth and if being cut it will cause the tuber not to grow well. Descriptions regarding the use of suweg for fish feed can be seen more clearly in Figure 3.

The use of suweg tubers by the community for traditional ceremonies, including the traditional ceremony in building a house (locally called ngadegkeun bumi), in the overtime (ngarot), and 4- or 7-months pregnancy (babarit). For all those traditional ceremonies, the raw suweg tubers are generally served or stored directly in the container/place of offerings or cooked (steamed made $u r a b$ ) first before serving.

Table 1. Utilization of suweg by the community of Cisoka Village, Majalengka District, West Java Province, Indonesia

\begin{tabular}{|c|c|c|c|}
\hline Type of utilization & Parts of plant used & Reason for utilization & Utilization technique \\
\hline Supplementary food/ snack & Tuber & It tastes good, makes you full & Steamed \\
\hline Fish feed & Leaf and petiole & Low cost, liked by fish & $\begin{array}{l}\text { Leaf blades and petioles are directly given to } \\
\text { fish in ponds or chopped first }\end{array}$ \\
\hline Traditional ceremony & Tuber & As one of 7 tubers that must be present & Tubers are served directly or cooked first \\
\hline
\end{tabular}




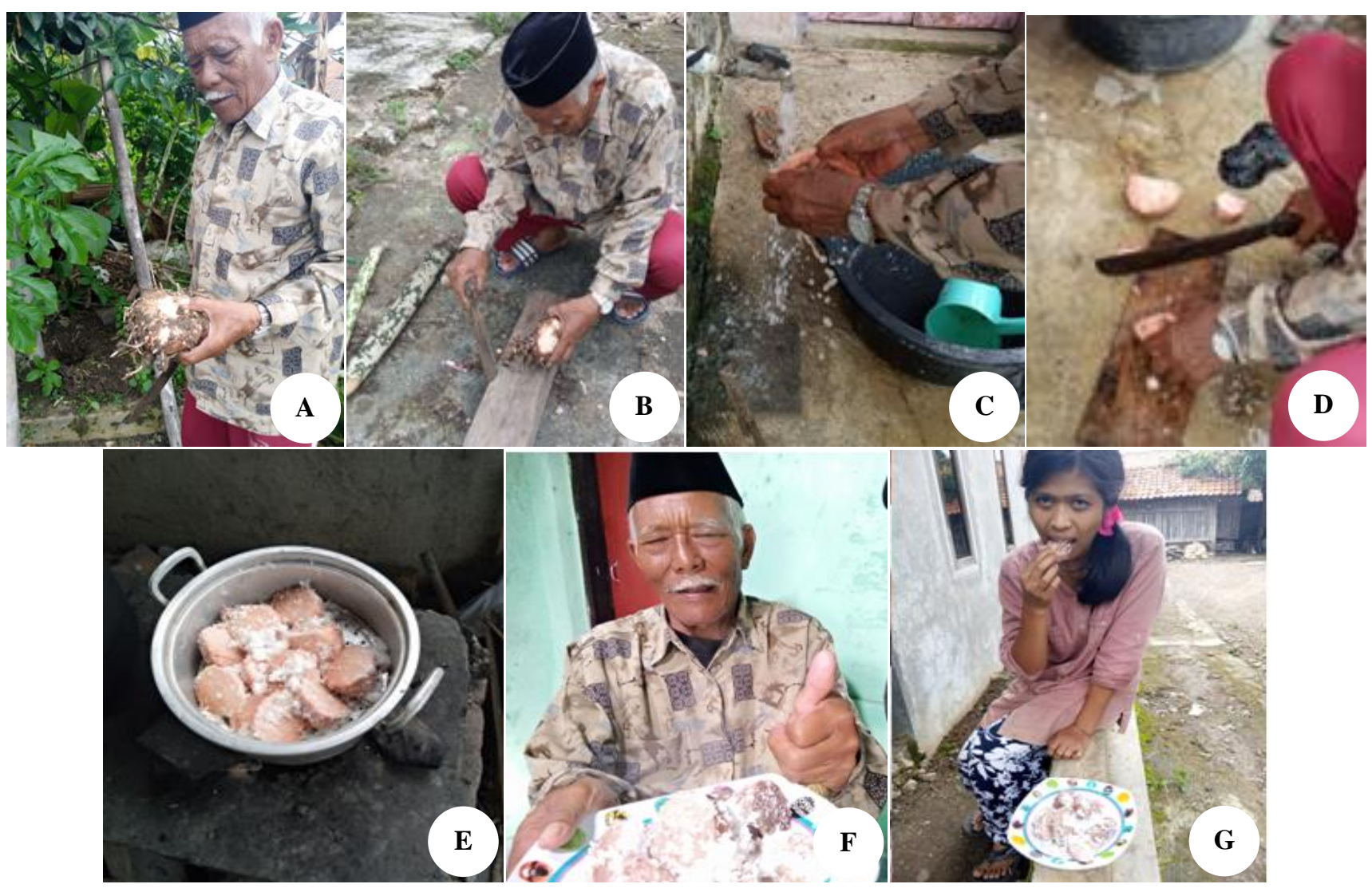

Figure 2. Suweg tubers used as food. A. Suweg tuber, B. Stripping the tuber skin, C. Washing the tuber skin, D. Sliced tubers, E. Boiling process of suweg tuber, F. Serving steamed suweg, G. Consuming steamed suweg

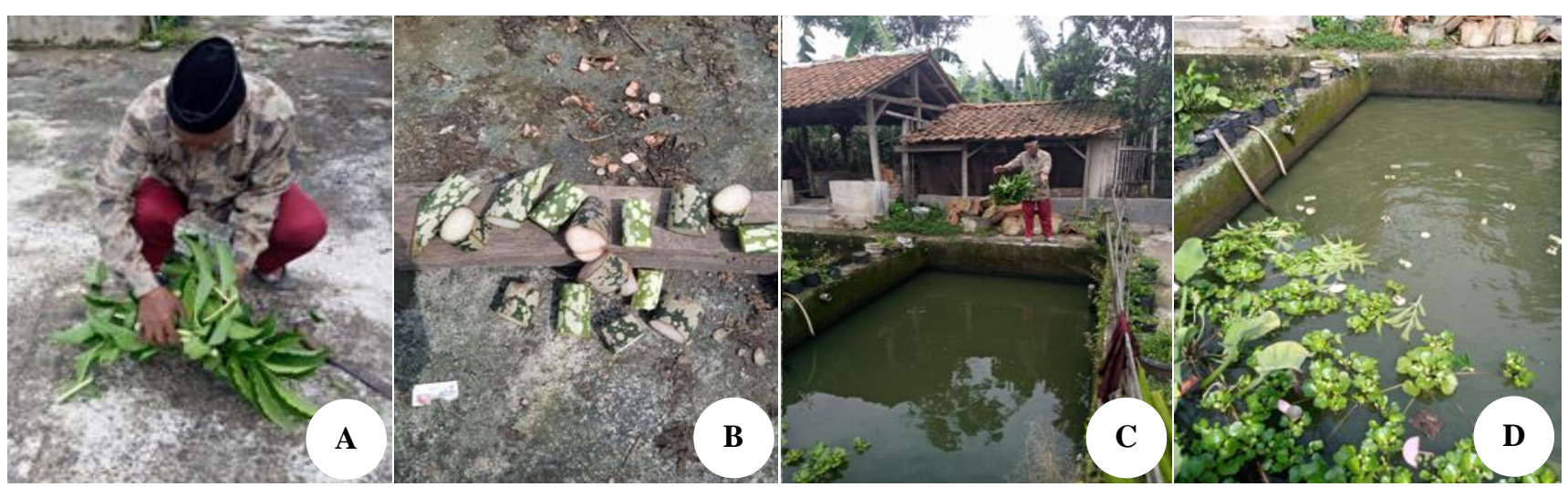

Figure 3. Suweg as fish feed. A-B. Cutting petiole and leaf blade of suweg; C-D. Throwhing suweg leaves to feed fish in a pond

The use of suweg by the community in Cisoka is in line with some other scientific information (ethical views). Mandal et al. (2016) state that suweg are essential plants for food security in several developing countries. Yuzammi (2018) states that suweg can be developed into food crops. Erskine (2015) mentions that this plant is used by the people of Timor-Leste for food. Meanwhile, Mukherjee et al. (2014) inform that suweg are edible plants.
Utilization of suweg for food is quite rational because suweg tubers contain phytochemical compounds such as carbohydrates (De et al. 2010; Singh et al. 2013). Septiani et al. (2015) state that suweg tubers have a high carbohydrate content of 86.6-90.2\%. More specifically, An et al. (2010) stated that suweg has glucomannan content. This compound is a carbohydrate with the main constituents are D-mannose and D-glucose (European 
Commission 2001; Tester and Al-Ghazzewi 2013). Glucomannan content in suweg tubers is around 1-19\% of dry weight (Mekkerdchoo 2016). In addition, Dey et al. (2017) state that this plant contains several phytochemical compounds such as carbohydrates, proteins, steroids, flavonoids, tannins and other phenolic compounds, glycosides and alkaloids, amino acids, fats and oils. Singh et al. (2016) also mentioned that suweg has nutritional content such as carbohydrates, flour, ascorbic acid, protein, $\beta$-carotene, and total phenol. Quantitatively, Srivastava et al. (2014) stated that the tubers of the suweg plant contain $11.53 \%$ protein, $3.52 \%$ fat, 70.75 carbohydrates and $14.32 \%$ crude fiber, $2.24 \mu \mathrm{g} / \mathrm{g}$ nitrogen, phosphorus 4.53 $\mu \mathrm{g} / \mathrm{g}$, potassium $38.1 \mu \mathrm{g} / \mathrm{g}$, magnesium $119.2 \mu \mathrm{g} / \mathrm{g}$, zinc $23.1 \mu \mathrm{g} / \mathrm{g}$, chromium $8.9 \mu \mathrm{g} / \mathrm{g}$, copper $32.6 \mu \mathrm{g} / \mathrm{g}$, iron 340.2 $\mu \mathrm{g} / \mathrm{g}$, and manganese $6.6 \mu \mathrm{g} / \mathrm{g}$.

The use of suweg in Cisoka for subsistence living is in line with Irwan et al. (2018) that plants grown in home garden serve as family food. More generally, Molebatsi et al. (2010) stated that plants that grow in home garden are aimed at food sources. Meanwhile, processing suweg by Cisoka's community to be used as food, this is commensurate with processing suweg by the community elsewhere. Hasanah et al. (2014) states that the people in Bantarkawung Sub-district, Brebes District utilize suweg to be processed into food by boiling and making compote, and making flour.

Regarding the knowledge that before steaming suweg needs to be thinly sliced and washed to relieve itchiness, this is in line with Chairiyah et al. (2016) that variations of calcium oxalate contained. Calcium oxalate rafida can cause itchiness in the skin, mouth and throat (Bradbury and Nixon 1998; Lewu et al. 2010; Singh et al. 2018). Meanwhile, Lukitaningsih et al. (2012) find that suweg tubers contain calcium oxalate which can cause itchiness when in contact with the skin, so it needs to be removed through the washing process. Widari and Rasminto (2018) concluded that tubal oxalate levels could be reduced through boiling at $80^{\circ} \mathrm{C}$ in $8 \% \mathrm{NaCl}$ solution for 25 minutes. Dewi et al. (2017) state that the levels of oxalate in taro tubers, plants that are related to suweg, can be reduced through steaming by the addition of activated charcoal. The knowledge that steamed suweg can be added salt, apart from to enhance the taste, is also likely not to adversely affect kidney function (Singh et al. 2018).

The use of suweg in Cisoka for fish feed is in line with what was informed by Mutaqin et al. (2018) that suweg and several other plants belonging to the family Araceae, such as Colocasia esculenta, Xanthosoma sagittifolium, and Alocasia macrorrhizos are commonly used for fish food. Darmayanti (2015) also mentioned that the leaves of taro, plant that is closely related to suweg, contain crude protein which can be used as fish food. Dorothy et al. (2018) state that the source of protein for fish feed derived from plants is low cost and environmentally friendly.

Related to common knowledge (emic views) suweg in Cisoka is used for some traditional ceremonies is in line with the results of other studies in which suweg is one of species from Araceae family which is used as a complement to traditional Hindu religious ceremonies (Warseno et al. 2013). Asih and Kurniawan (2019) mention that suweg tubers in Bali are used in traditional ceremonies, namely the Adult Ceremony, Rsi, Human, Pitra, and Bhuta Yadnya. In addition, Ayuningtyas and Hakim (2014) find that this plant is one of 62 species used in a series of ceremonies to welcome the Sura month in Sedudo waterfall, Nganjuk District, East Java Province. People in Cisoka also used suweg as one of the 7 tubers that must be present in a traditional ceremony. Darpan et al. (2013) mention that tubers used in traditional ceremonies include sweet potatoes, cassava, sago, and taro. These tubers in traditional ceremonies are often locally termed as polo pendem or underground plants (Fauza 2010; Hakim 2014).

\section{Cultivation of suweg in Cisoka Village}

The informants said that in Cisoka suweg is not actually cultivated intensively, so that its management is also relatively low cost. The informants informed that the main reason causing suweg not to be cultivated intensively was partly because suweg did not have economic value as it is not commonly traded. Several stages in suweg cultivation in Cisoka Village is presented in Table 2.

Traditionally, in suweg cultivation, residents usually grow seedlings from bud/tubers and peeled tubers. The buds or peeled tubers are not treated specifically, for example, covered with ash, soaked, or given a fungicide. Suweg seedling sources that are intentionally planted can come from family or neighbors. Land preparation for suweg seedling that is intentionally planted in agroecosystem types, such as home gardens and gardens, follows land preparation for other staple crops. Suweg planting techniques generally are by burying buds or peeled tubers in a hole in the soil (up to a depth of about 10-15 $\mathrm{cm}$, with a hole width depending on the size of the seed) or left on the ground. Suweg that grow or are intentionally planted on cultivated land types are not specifically treated. There is no or lacked fertilization or pest/weed control specifically. If suweg grows on cultivated land, then the treatment of the staple crop will directly or indirectly affect the growth of the suweg. The treatments include controlling weeds, or in the local language commonly called ngored. In addition, tubers can be harvested if suweg is at least around 4 months or one planting season, during the dry season, and the stems have withered or fallen. If suweg tubers are harvested during the rainy season, the tubers are not tasty and watery or beueuy (in the local language). Another thing, if the tubers are harvested when the stems have not withered or are still in its infancy, then the tubers are itchy, small in size, not tasty and hard or cangorljagreug in local language. Likewise, if the tubers are not harvested in one season, then the tubers should be turned over so that they get bigger. Harvesting does not special preparation such as traditional ceremonies or certain forms of ritual. The cultivation stage can be seen in Figure 4. 
Table 2. Stage and cost of suweg cultivation in Cisoka Village, Majalengka District, West Java Province, Indonesia

\begin{tabular}{lll}
\hline Stages & Processing & Cost \\
\hline Seedling preparation & Performed by workers in the family & There is no specific cost \\
Land preparation & Performed by workers in the family & There is no specific cost \\
Planting and maintenance of plant & Performed by workers in the family & There is no specific cost \\
Harvest & Performed by workers in the family & There is no specific cost \\
\hline
\end{tabular}

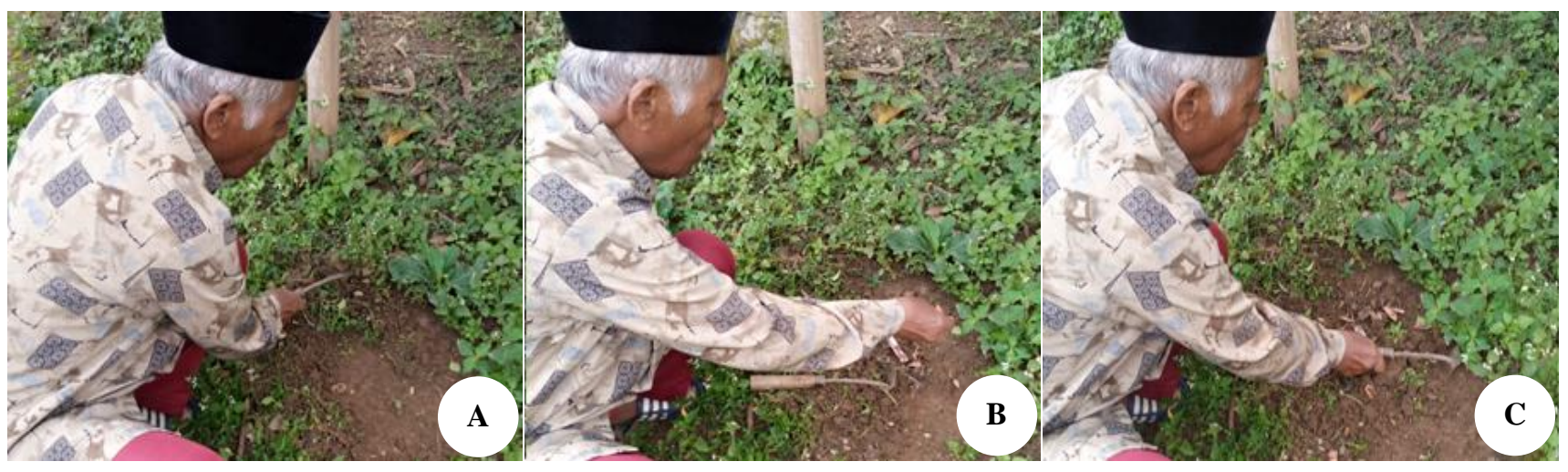

Figure 4. Planting suweg seed: A. Preparation of hole; B. Planting seeds in the hole; C. Covering seeds with soil

The information gathered from the informants above can be explained with some results of scientific studies (ethical views). The absence of intensive cultivation is possible, this may be due to an intensive market economy penetration into rural areas which causes changes in the food consumption patterns of villagers (Iskandar and Iskandar 2015). Nevertheless, the village community still has knowledge about the use of suweg. Oliveira et al. (2019) state that loss of access to resources is not directly related to loss of knowledge about resources. Furthermore, in general, Iskandar et al. (2018) state that the existence and genetic diversity of plants is determined by local cultural and ecological factors. Sulistyowati et al. (2014) concluded that economic factors influence crop cultivation or population. Blancas et al. (2013) inform that the availability of quantity and quality of uses underlies crop management. More specifically, Anil et al. (2011) informed that some species grow wild and some are cultivated. Likewise, Erskine (2015) revealed that the suweg in TimorLeste is a wild plant.

Related to information from public knowledge (emic view) that suweg is propagated by using tubers and peeled tubers, this is in line with the opinion of Cahyaningsih and Siregar (2013) that the propagation of the suweg is originated from the tubers and the tuber slices containing the buds, where tuber cubs are the best source that produce more number of buds that germinate more. Ravi et al. (2009) allude to seeds originating from tubers or tuber slices, where their size affects growth. Hasanah et al. (2014) inform that seed originated from tuber saplings, buds on tuber skin, or seeds. Sulistiyo et al. (2015) informed that prospective tuber buds are on the surface of tuber skin.
Land preparation for suweg cultivation in Cisoka follows the land preparation for other staple crops. Mutaqin et al. (2018) inform that the people of Cisoka generally prepare the land at the beginning of the rainy season in September and October. For example, the cultivation preparation of taro, plant which is related to suweg, is done by the following stages: firstly, the soil is cleared of weeds; secondly, the cleared soil is plowed using hoes; thirdly, bunds of soil are made while the soil is cleansed from the roots of weed plants; finally, holes with a distance of $50 \mathrm{~cm}$ from another are dug.

The informants in Cisoka said that for germinating suweg, the buds/peeled tubers are buried in the ground. This is in line with what was informed by Mutaqin et al. (2008) related to planting taro, a plant from similar family with suweg, although there are differences in planting techniques for each species. In general, the Cisoka community plant crops from Araceae family using the following steps: first, the hole is made with size of $20 \times 20$ x $20 \mathrm{~cm}$; second, each seedling is placed in the hole; third, fertilizer is sown on each hole that has been planted with seedling; fourth, the hole that has been planted with seedling and added with fertilizer, filled with soil until the surface is the same as ground level.

Associated with the statement of the community that the treatment of staple crops will have an impact on plant growth, this is in line with the statement of Sekhar et al. (2017) that grass control, especially mulching with black politeness will affect all growth periods of suweg. Likewise, Kuamr et al. (2019) concluded that the use of herbicides to control weeds can increase plant growth and suweg tubers.

Related to the opinion of the community that harvesting suweg is done in one planting season or during 
the dry season or when the suweg stalk has fallen, this is in line with the statement of Ravi et al. (2009) that suweg tubers will be maximum harvested after around 8 months. Kumar et al. (2015) inform that suweg is ready for harvest at 7-8 months after planting. Narayan et al. (2018) mention that suweg is commercially harvested after 6-7 months depending on market demand, but for the purpose of being harvested seeds after 9-10 months. Chairiyah et al. (2014) informed that the tubers of Amorphophallus muelleri Blume, plants that are related to suweg, are harvested when the plants fell, because they have high glucomannan content. Likewise, Hasbullah and Umiyati (2017) inform that some characteristics of suweg root flour such as edible portion, bulk density, and starch are higher in the dormant phase than in the vegetative phase, where the dormant phase occurs during the dry season and the vegetative phase occurs during the rainy season. In addition, Chairiyah et al. (2011) informed that tuber organs, leaf blades, and leaf stalks of Amorphophallus muelleri Blume, which are related to suweg, have calcium oxalate crystals, especially those that grow in areas exposed to sunlight.

In general, planting suweg begins with the following process: tuber sliced into pieces are used as planting material and take 3-4 weeks timer for the development of sprouts. Plants can be vegetatively propagated through corms that can be planted in the prepare pits $(40 \mathrm{~cm} \times 40$ $\mathrm{cm} \times 40 \mathrm{~cm}$ ) filled with decomposed cow dost compost and sandy loam soil (Misra et al. 2002; Singh and Wadhwa 2014). In more detail, Kumar et al. (2015) informed that the cultivation practice of suweg is as follows. The land is prepared by thorough plowing in different directions. The land is leveled after removing the weed twigs and rocks. Ridges and furrows are made at $73 \mathrm{~cm}$ apart. The tubers are sown $63 \mathrm{~cm}$ apart in the furrows, immediately the land was irrigated through the furrows. As a result of this, there will be $73 \mathrm{~cm}$ apart from row to row and $58 \mathrm{~cm}$ plant to plant. Before planting, the corms are air-dried for about 40-45 days, when they are placed in field areas, after drying period the corms are vertically cut into pieces (approximate size- 750-100g) and each piece bears apical bud. Suweg corm is having central bud situated on the top of the corms. Due to apical dominance, it sprouts first and earliest, other buds remain dormant, retaining the portion of the central buds vertical cut, is essential for higher percentage of sprouting. Corm set of $100 \mathrm{~g}$ sizes could be prepared from whole tubers by cutting vertically. Thus, obtained tuber pieces are dried in shade for 24 hours. Afterward planting material is buried vertically in the furrows. This is followed by digging interspaces and light earthing up, one month later, along with intercultural operations like de-weeding, earthing up. Tuber starts sprouting after 2-3 months. The crop matures in 6-8 months after planting indicated by yellowing followed by complete drying of the pseudostem.

Based on the results of this study it can be concluded that suweg (Amorphophallus paeoniifolius (Dennst.) Nicolson has been known and utilized by the people of Cisoka Village, Cikijing Sub-district, Majalengka District since the beginning until nowadays. This plant is used by the community for various purposes, namely supplementary food, fish feed, and traditional ceremonies.
Special use of traditional ceremonies is rarely done. Suweg is generally used by old age groups or certain groups such as pond owners. Suweg in Cisoka Village is not cultivated intensively since it lacks economic value or does not become an agricultural commodity.

\section{ACKNOWLEDGEMENTS}

The authors would like to thank everyone or stakeholders who have supported this research, especially Rector of Padjadjaran University, Dean of Postgraduate School of Padjadjaran University, the Head of Study Program of Environmental School of Postgraduate School of Padjadjaran University, the Head of Cisoka Village, and many people in Cisoka Village. This research was supported by the Academic Leadership Grant of Prof. Johan Iskandar.

\section{REFERENCES}

Albuquerque UP, Paiva de Lucena RF, de Frietas Lins Neto EM. 2014. Selection of Research Participants. In: Albuquerque UP, Cruz da Cunha LVF, Paiva de Lucena RF, Alves RRN (eds) Methods and Techniques in Ethnobiology and Ethnoecology. Springer Science+ Business Media, New York.

An NT, Thien DT, Dong NT, Dung PL, Du NV. 2010. Characterization of glucomannan from some Amorphophallus species in Vietnam. Carbohydr Polym 80: 308-311.

Anil SR, Siril EA, Beevy SS. 2011. Morphological variability in 17 wild elephant foot yam (Amorphophallus paeoniifolius) collections from southwest India. Genet Resour Crop Evol 58 (8): 1263-1274.

Asih NPS, Kurniawan A. 2019. Bali Araceae study: diversity and potential. Widya Biologi 10 (2): 135-147. [Indonesian]

Ayuningtyas P, Hakim L. 2014. Ethnobotany ceremony for welcoming the month of Sura at the Sebudo Waterfall Nature Tourism Complex, Nganjuk. Biotropika 2 (1): 31-39. [Indonesian]

Balick M, Cox PA. 1997. Plants, People and Culture: The Science of Ethnobotany. Scientific American Library, New York.

Berkes F. 2008. Sacred Ecology. 2nd ed. Routledge, New York.

Blancas J, Casas A, Salicrup DP, Caballero J, Vega E. 2013. Ecological and socio-cultural factors influencing plant management in Nahuatl communities of the Tehuacan Valley, Mexico. J Ethnobiol Ethnomed 9: 1-22.

Bradbury JH, Nixon RW. 1998. The acridity of raphides from edible aroids. J Sci Food Agri 76: 608-616.

Cahyaningsih R, Siregar HM. 2013. Propagation on suweg (Amorphophallus paeoniifolius (Dennst.) Nicolson) using tuber and rachis cutting manipulated with plant growth regulator. Berita Biologi 12 (1): 87-95. [Indonesian]

Central Statistics Agency of Majalengka District. 2019. Cikijing district in figures. Central Statistics Agency of Majalengka District, Majalengka. [Indonesian]

Chairiyah N, Harijati N, Mastuti R. 2011. Kristal kalsium oksalat (CaOx) pada porang (Amorphophallus muelleri Blume) yang terpapar dan tidak terpapar matahari. Natural B 1 (2): 130-138. [Indonesian]

Chairiyah N, Harijati N, Mastuti R. 2014. Effect of harvest time on glucomannan content in porang tubers (Amorphophallus muelleri Blume) third growing period. Res J Life Sci 1 (1): 37-42. [Indonesian]

Chairiyah N, Harijati N, Mastuti R. 2016. Variation of Calcium Oxalate $(\mathrm{CaOx})$ crystals in porang corms (Amorphophallus muelleri Blume) at different harvest time. Am J Plant Sci 7: 306-315.

Cikijing Sub-district Agricultural Counseling Center. 2019. BPP agriculture counseling program in Cikijing Sub-district. Cikijing Subdistrict Agricultural Counseling Center, Majalengka. [Indonesian]

Cisoka Village Government. 2016. Profile of Cisoka Village, Cikijing Sub-district, Majalengka District. Cisoka Village Government, Majalengka. [Indonesian] 
Cotton CM. 1996. Ethnobotany: Principles and Applications. John Willey and Sons, England.

Cunningham AB. 2001. Applied Ethnobotany: People, World Plant Use and Conservation. Earthscan, London.

Darmayanti RW. 2015. Content of Crude Fiber and Crude Protein in Taro Leaves which is Fermented with Probiotic as Fish Feed Ingredients. [Skripsi]. Faculty of Fisheries and Maritime Affairs, Universitas Airlangga, Surabaya. [Indonesian]

Darpan, Abdurachman, Soepandi A, Muanas D, Rusyana Y. 2013 Compendium of the term Sundanese traditional farming system. First ed. PT Dunia Pustaka Jaya, Bandung. [Indonesian]

De S, Dey YN, Ghosh AK, 2010. Phytochemical investigation and chromatographic evaluation of the different extracts of tuber of Amorphophallus paeoniifolius (Araceae). Intl J Pharmaceutic Biomed Res 1 (5): 150-157.

Dewi SK, Dwiloka B, Setiani BE. 2017. The reduction of oxalate level in taro tuber with the addition of active carbon using steaming method. J Aplikasi Teknologi Pangan 6 (2): 1-4. [Indonesian]

Dey YN, Wanjari MM, Kumar D, Lomash V, Gaidhanis SND, Jadhav AD. 2017. Oral toxicity of elephant foot yam (Amorphophallus paeoniifolius) tuber in mice. J Pharma Pharmacog Res 5 (1): 55-68.

Dharmadasa RM, Akalanka GC, Muthukumarana PRM, Wijesekara RGS 2016. Ethnopharmacological survey on medicinal plants used in snakebite treatments in Western and Sabaragamuwa Provinces in Sri Lanka. J Ethnopharm 179: 110-127.

Dorothy MS, Raman S, Nautiyal V, Singh K, Yogananda T, Kamei M. 2018. Use of potential plant leaves as ingredient in fish feed-a review. Intl J Curr Microbiol App Sci 7 (7): 112-125.

Ellen RF, Harris H. 2000. Introduction. In: Ellen RF, Parkes P, Bicker A (eds), Indigenous Environmental Knowledge and Its Transformation Critical Anthropological Perspective. Hardwood Academic Publisher, Amsterdam.

Erskine W, Ximenes A, Glazebrook D, Costa M, Lopes M, Spyckerelle L, Williams R, Nesbitt H. 2015. The role of wild foods in food security: the example of Timor-Leste. Food Secur 7 (1): 55-65.

European Commission. 2001. Commission Directive 2001/30/EC of 2001, amending Directive 96/77/EC laying down specific purity criteria on food additives other than colours and sweeteners. European Commission, Brussel.

Fauza N. 2010. Traditional Jamasan Heritage Ceremony Terms in the Gajah Mungkur Reservoir Wonogiri (An Ethnolinguistic Study). [Thesis]. Faculty of Literature and Fine Arts, Sebelas Maret University, Surakarta. [Indonesian]

Girardi C, Butaud JF, Ollier C, Ingert N, Weniger B, Raharivelomanana P, Moretti C. 2015. Herbal medicine in the Marquesas Islands. J Ethnopharm 161: 200-213

Hakim L. 2014. Ethnobotany and Home Garden Management: Health Food Security, and Agrotourism. Penerbit Selaras, Malang. [Indonesian]

Handavu F, Chirwa PWC, Syampungani S. 2019. Social-economic factor influencing land-use and land-cover changes in the miombo woodlands of the Copperbelt Province in Zambia. For Pol Econ 100: 75-94.

Hasanah U, Hadi EP, Hidayah HA. 2014. Diversity and uses of tuber as alternative food sources in Bantarkawung Brebes District. Biosfera 31 (2): 61-70. [Indonesian]

Hasbullah UHA, Umiyati R. 2017. Differences in physical, chemical, and sensory properties of Suweg tuber flour (Amorphophallus campanulatus $\mathrm{BI}$ ) in the dormant and vegetative phases. Planta Tropika: J Agrosains 5 (2): 70-78. [Indonesian]

Irwan SNR, Rogomulyo R, and Trisnowati. 2018. Utilization of "pekarangan" through productive landscape development in Mangun Village, Bantul District Yogyakarta. J Ilmu Pertanian Indonesia, 23 (2): 148-157. [Indonesian]

Iskandar BS, Iskandar J, Irawan I, Suroso, Partasasmita R. 2019. The development of coffee cultivation in the traditional agroforestry of mixed-garden (dukuh lembur) to provide social-economic benefit for the Outer Baduy Community, South Banten, Indonesia. Biodiversitas 20: 2958-2969.

Iskandar BS, Iskandar J, Wibawa HA, Partasasmita R. 2017. Farmers and tumpang sari: Case study in Palintang Hamlet, Cipanjalu Village, Bandung, Indonesia. Biodiversitas 18: 1135-1149.

Iskandar J, Iskandar BS, Partasasmita R. 2018. Review: The impact of social and economic change on domesticated plant diversity with special reference to wet rice filed and home-garden farming of West Java, Indonesia. Biodiversitas 19 (2): 502-524.
Iskandar J, Iskandar BS. 2011. Sundanese Agroekosystem. Kiblat, Bandung. [Indonesian]

Iskandar J, Iskandar BS. 2015. Ethnobotanical study on food crop diversity in swidden agroforestry agriculture to support food security of Baduy community. Prosiding Seminar Nasional Masyarakat Biodiversitas Indonesia 1 (6): 1265-1272. [Indonesian]

Iskandar J, Iskandar BS. 2016. Plant architecture: the structure of rural homegarden and the green open space. Teknosain, Yogyakarta. [Indonesian].

Iskandar J. 2017. Human Ecology and Sustainable Development. Edition Revision, PSMIL, Unpad, Bandung. [Indonesian]

Iskandar J. 2018. Ethnobiology, ethnoecology, and sustainable development. Plantaxia, Yogyakarta. [Indonesian]

Kuamr JS, More SJ, Byju G, Sunitha S, Veena SS, Nedunchezhiyan M, Ravi V. 2019. Effect of new generation herbicides on weed management, corm yield and economics of elephant foot yam [Amorphophallus paeoniifolius (Dennst.) Nicolson]. Intl J Chem Stud 7 (3): 1213-1218.

Kumar PRK, Kolli SK, Suneetha J, Hemanth G. 2015. Cultivation of Amorphophallus paeoniifolius (Dennst) Nicolson (Elephant foot yam) in Kovvur Mandal of West Gidavari District, Andhrapradesh India. Intl J Curr Res 7 (5): 15549-15553.

Kusmana C, Hikmat A. 2015. The Biodiversity of flora in Indonesia. J Pengelolaan Sumberdaya Alam dan Lingkungan 5 (2): 187-198. [Indonesian]

Lewu MN, Adebola PO, Afolayan AJ. 2010. Effect of cooking on the mineral contents and anti-nutritional factors in seven accessions of Colocasia esculenta (L.) Schott growing in South Africa. J Food Compos Anal 23: 389-393.

Lizarralde M. 2004. Indigenous knowledge and conservation of the rainforest: Ethnobotany of the Bari of Venezuela. In: Carlson TJS, Maffi L (eds) Ethnobotany and Conservation of Biocultural Diversity. New York Botanical Garden, New York.

Lukitaningsih E, Rumiyati, Puspitasari I. 2012. Study of glycemic index and macronutrient content from tubers to find alternative functional food. Pharmacon 13 (1): 18-23. [Indonesian]

Makruf E, Iswadi H. 2015. Information Technology Collection (KIT) for tuber cultivation. Balai Pengkajian Teknologi Pertanian (BPTP) Bengkulu, Bengkulu. [Indonesian]

Mandal R, Nag S, Tarafdar J, Mitra S. 2016. A comparison of efficiency parameters of SSR markers genetic diversity analysis in Amorphophallus paeoniifolius (Dennst.) Nicolson. Braz Arch Biol Tech 59: 1-7.

Mardiyaningsih DI, Dharmawan AH, Tonny F. 2010. The dynamics of the traditional and modern farmers' livelihood systems in West Java. Sodality, 4 (1): 115-145. [Indonesian]

Maroyi A, Cheikhyoussef A. 2015. A comparative study of medicinal plants used in rural areas of Namibia and Zimbabwe. Indian J Trad Knowl 14 (3): 401-406.

Martin GJ. 1995. Ethnobotany: A Method Manual. Chapman and Hall, London.

Mekkerdchoo O, Borompichaichartkul C, Perrigo AL, Srzednicki G, Prakitchaiwattana C, Antonelli A. 2016. Tracing the evolution and economic potential of konjac glucomannan in Amorphophallus species (Araceae) using molecular phylogeny and RAPD markers. Phytotaxa 282 (2): 81-106.

Misra, RS, Nedunchezhiyan M, Swamy TMS, Edison S. 2002. Mass multiplication techniques for producing quality planting material of Amorphophallus paeoniifolius (Dennst.) Nicolson (Araceae). Aroideana 25: 78-87.

Molebatsi LY, Siebert SJ, Cilliers SS, Lubbe CS, Davoren E. 2010. The Tswana tshimo: A homegarden system of useful plants with a particular layout and function. Afr J Agri Res 5 (21): 2952-2963.

Mukherjee A, Banerjee A, Sinhababu A, Singh PP. 2014. The genus Amorphophallus: Cyto-histo-molecular genesis and commercial prospects. Intl J Innov Horticult 3 (1): 13-21

Mustafa B, Hajdari A, Pieroni A, Pulaj B, Koro X, Quave CL. 2015. A cross-cultural comparison of folk plant uses among Albanians, Bosniaks, Gorani, and Turks living in South Kosovo. J Ethnobio Ethnomed 11 (39): 1-26.

Mutaqin AZ, FatharaniM, Iskandar J, Partasasmita R. 2018. Utilization of Araceae by local community in Cisoka Village, Cikijing Sub-district, Majalengka District, West Java, Indonesia. Biodiversitas 19 (2): 560571.

Mutaqin AZ, Kurniadie D, Iskandar J, Nurzaman M, Partasasmita R. 2020. Ethnobotany of suweg (Amorphophallus paeoniifolius): Folk 
classification, habitat, and traditional conservation in Cisoka Village, Majalengka District, Cimanuk Watershed Region, Indonesia Biodiversitas 2 (2): 546-555.

Narayan A, Prasad R, Singh PP, Singh RS. 2018. Elephant foot yam (Amorphophallus paeoniifolius): money-spinning tuber crop for doubling farmers income of Bihar. Intl J Curr Microbiol App Sci 7: 1014-1021.

Newing H, Eagle CM, Puri RK, Watson CW. 2011. Conducting Research in Conservation: Social Science Methods and Practice. Routledge, London.

Njurumana G. 2016. Village communities and flora biodiversity management in the yard system in Central Sumba District. J Penelitian Kehutanan Wallacea, 5 (1): 25-36. [Indonesian]

Oliveira ES, Albuquerque UP, Alves AGC, Ramos MA. 2019. Is loca ecological knowledge altered after changes on the way people obtain natural resources? J Arid Environ 167: 74-79.

Partasasmita R, Iskandar BS, Nuraeni S, Iskandar J. 2019. Impact of the green revolution on the gender's role in wet rice farming: A case study in Karangwangi Village, Cianjur District, West Java, Indonesia. Biodiversitas 20: 23-36

Prihatini J, Iskandar J, Partasasmita R. 2018. Structure of the commercial homegarden: a case study in village Sukapura, sudistrict of Kartesari, Dustrik if Bandung, Upper Citarum Watershed, West Java, Indonesia. Biotika 16 (2): 5-14 [Indonesian]

Ramanathan R, Bhuvaneswari R, Indhu M, Subramanian G, Dhandapani R. 2014. Survey of ethnobotanical observation on wild tuberous medicinal plants of Kollihills, Namakkal District, Tamilnadu. J Med Plants Stud 2 (4): 50-58.

Ravi V, Ravindran CS, Suja G. 2009. Growth and productivity of elephant foot yam (Amorphophallus paeoniifolius (Dennst.) Nicolson: an overview. J Root Crops 35 (2): 131-142.

Regulation of the Head of the Central Statistics Agency Number 37 of 2010 concerning the classification of urban and rural areas in Indonesia [Indonesia]

Santosa E, Lian CL, Sugiyama N, Misra RS, Boonkorkaew P, Thanomchit K. 2017. Population structure of elephant foot yams (Amorphophallus paeoniifolius (Dennst.) Nicolson) in Asia. PLoS ONE 12 (6): e0180000. DOI: 10.1371/journal.pone. 0180000 .

Sekhar L, Thomas CG, Sindhu PV. 2017. Weed management in elephan foot yam (Amorphophallus paeoniifolius (Dennst.) Nicholson). J Trop Agri 55 (1): 76-80.

Septiani D, Hendrawan Y, Yulianingsih R. 2015. Physical, chemical, and organoleptic characteristics test of suweg (Amorphophallus campanulatus B) flour as an alternative food. J Bioproses Komoditas Tropis 3 (1): 11-18. [Indonesian]

Sillitoe P. 2002. Globalizing Indigenous Knowledge. In: Sillitoe P, Bicker A, Pottier J (eds) Participating in Development: Approaches to Indigenous Knowledge. Routledge, London

Singh A, Chaurasiya A, Mitra S. 2016. Assessment of nutritional composition in elephant foot yam (Amorphophallus paeoniifolius Dennst. Nicolson) cultivars. Intl J Food Stud 5: 146-157.
Singh A, Srivastava KC, Banerjee A, Wadhwa N. 2013. Phytochemical analysis of peel of Amorphophallus paeoniifolius. Intl J Pharma Bio Sci 4 (3): 810-815.

Singh A, Wadhwa N. 2014. A review on multiple potentials of aroid: Amorphophallus paeoniifolius. Intl J Pharm Sci Rev Res 24 (1): 5560.

Singh AK, Chaurasiya AK, Mitra S. 2018. Oxalate content in elephant foot yam (Amorphophallus paeoniifolius Dennst-Nicolson) Dry and Fry cubes. J Pharm Phytochem 7 (2): 2905-2909.

Singh B, Tham BBT, Rabha NN. 2010. Taxonomical notes on Amorphophallus paeoniifolius (Dennst.) Nicolson var. campanulatus (Decne) Sivadasan (gigantic flower): a new record for Meghalaya. J Econ Taxon Bot 34 (3): 492-492.

Srivastava S, Verma D, Srivastava A, Tiwari SS, Dixit B, Sing RS, Rawat AKS. 2014. Phytochemical and nutritional evaluation of Amorphophallus campanulatus (Roxb.) Blume. J Nut Food Sci 4 (3): $1-6$.

Suja G, Sundaresan S, John KS, Sreekumar J, Misra RS. 2012. Higher yield, profit and soil quality from organic farming of elephant foot yam. Agron Sustain Dev 32: 755-764.

Sulistiyo RH, Soetopo L, Damanhuri. 2015. Exploration and identification morphological character of elephant foot yam (Amorphophallus muelleri B.) in East Java. J Produksi Tanaman 3 (5): 353-361. [Indonesian]

Sulistyowati PV, Kendarini N, Respatijarti. 2014. Observation of the existence of taro plant genus Colocasia and Xanthosoma in Kedungkandang Subdistrict and Ampel Gading Subdistrict, Malang. J Produksi Tanaman 2 (2): 86-93. [Indonesian]

Tester RF, Al-Ghazzewi FH. 2013. Mannans and health, with a special focus on glucomannans. Food Res Intl 50: 384-391.

The Drafting Team of the Ministry of National Education. 2011. Big Indonesian dictionary language center. Gramedia Pustaka Utama, Jakarta. [Indonesian]

Warseno T, Asih NPS, Kurniawan A. 2013. Preservation and use of Araceae species as a Hindu ceremonial plant at the Bali "Eka Karya" Botanic Garden. Prosiding Seminar Nasional Biodiversitas 1: 115121. [Indonesian]

Widari NS, Rasmito A. 2019. Decreased levels of calcium oxalate in the tubers of porang (Amorphophallus oncophyllus) with the heating process in a solution of $\mathrm{NaCl}$. J Teknik Kimia 13 (1): 1-4. [Indonesia]

Wigna W, Khomsan A. 2011. Local wisdom in food diversification. Pangan 20 (3): 283-293. [Indonesian]

Yuzammi, Kurniawan A, Asih NPS, Erlinawati I, Hetterscheid W. 2017. The Amorphophallus of Indonesia. Center for Plant Conservation Botanic Gardens, Indonesian Institute of Sciences, Bogor.

Yuzammi. 2018. The diversity of aroids (Araceae) in Bogor Botanic Gardens, Indonesia: Collection, conservation and utilization. Biodiversitas 19 (1): 140-152

Zambrana NYP, Leret RC, Bussmann RW, Macia MJ. 2014. The influence of socioeconomic factors on traditional knowledge: a crossscale comparison of palm use in Northwestern South America. Ecol Soc 19 (4): 9 